\title{
PENGARUH PENAMBAHAN ADITIF BERBASIS MINYAK KELAPA SAWIT TERHADAP SIFAT MEKANIK KOMPOSIT KARET ALAM
}

\author{
The Effect of Oil Palm Based Rubber Additive to \\ the Mechanical Properties of Natural Rubber Composite \\ Mili PURBAYA $^{1 *}$, dan Sherly HANIFARIANTY ${ }^{2}$ \\ ${ }^{1)}$ Pusat Penelitian Karet \\ Jalan Raya Palembang - Pangkalan Balai KM 29 \\ Sembawa, Banyuasin 30953, Sumatera Selatan \\ *Email: mp_plazoe2000@yahoo.com \\ ${ }^{2)}$ Balai Penelitian Teknologi Karet, Pusat Penelitian Karet \\ Jalan Salak Nomor 1 Bogor 16128 Jawa Barat
}

Diterima : 21 September 2020 / Disetujui : 21 Desember 2020

\begin{abstract}
Natural rubber has many advantages which cannot be found in synthetic rubber, such as high rebound resilience and tensile strength, good tear strength and abrasion resistance, better viscoelasticity, and flexibility at low temperature. On the other hand natural rubber also has several disadvantages such as low resistance to heat, ozone, and sunlight, weak oil and hydrocarbon solvents resistance. The content of unsaturated fatty acids in palm oil is relatively high, around 37-56\% therefore palm oil is highly potential to be converted into dimer acid as the main ingredient in the synthesize of an bioelastomeric material. Test results of the experiment showed that the addition of palm oil based bioelastomer into rubber compound and vulcanizate increased the maximum torque, torque delta, hardness, tear strength, and compression set of the rubber. However it reduced the scorch time, optimum curing time, tensile strength, elongation at break, flex cracking resistance, and rebound resilience of the rubber. Thus, the oil resistance test result showed that B3 rubber compound formula (consisted of 7.5 phr palm oil based bioelastomer) has the smallest mass change value, therefore the rubber formula can be developed into oil resistant rubber based product.
\end{abstract}

Keywords: Bioelastomer; mechanical properties; palm oil; rubber products

\begin{abstract}
Abstrak
Karet alam memiliki keunggulan yang tidak dimiliki oleh karet sintesis, seperti daya pantul, kuat tarik, ketahanan sobek, ketahanan abrasi, viskoselastisitas, dan fleksibilitas pada suhu rendah. Namun karet alam juga memiliki kelemahan seperti ketahanan terhadap panas, ozon, dan sinar matahari serta ketahanan terhadap minyak, minyak tanah dan pelarut hidrokarbon yang rendah. Kandungan asam lemak tidak jenuh dalam minyak kelapa sawit relatif tinggi, sekitar 37-56 \% sehingga minyak kelapa sawit memiliki potensi dikonversikan menjadi asam dimer sebagai bahan utama dalam pembuatan bioelastomer. Hasil pengujian menunjukkan bahwa penambahan bioelastomer berbasis minyak kelapa sawit dapat meningkatkan nilai torsi maksimum, delta torsi, nilai kekerasan, kekuatan sobek, dan pampatan tetap dari kompon dan vulkanisat karet. Namun penambahan bioelastomer berbasis minyak kelapa sawit dalam kompon karet juga berakibat menurunkan waktu pra vulkanisasi, waktu pemasakan optimum, nilai tegangan putus, perpanjangan putus, ketahanan retak lentur, dan nilai kepegasan pantul. Hasil pengujian ketahanan minyak vulkanisat karet menunjukkan bahwa formula kompon karet B3 (mengandung 7,5 phr bioelastomer berbasis minyak kelapa sawit) memiliki nilai perubahan massa yang paling kecil sehingga berpotensi
\end{abstract}


dikembangkan menjadi produk barang jadi karet yang tahan terhadap minyak.

Kata Kunci: Barang jadi karet; bioelastomer; minyak kelapa sawit; sifat mekanik

\section{PENDAHULUAN}

Indonesia kaya akan sumber daya alam terutama di bidang perkebunan seperti perkebunan kelapa sawit. Hasil perkebunan kelapa sawit menempatkan Indonesia sebagai produsen kelapa sawit terbesar kedua di dunia setelah Malaysia. Perkebunan kelapa sawit menghasilkan Crude Palm Oil (CPO) yang umumnya diolah menjadi minyak sayur (vegetable oil). Minyak kelapa sawit memiliki kandungan asam lemak jenuh 44,7 - 53,2\% dan asam lemak tak jenuh 37 - $56 \%$ (Ketaren, 1986). Tingginya kandungan asam lemak tidak jenuh pada minyak kelapa sawit memungkinkan minyak sawit diolah menjadi produk olahan yang bersumber dari vegetable oil seperti bioelastomer.

Elastomer merupakan salah satu jenis polimer yang memiliki sifat elastis (kenyal) seperti karet. Bioelastomer adalah elastomer yang bersumber dari sumber daya alam yang dapat diperbaharui (renewable) dalam penelitian ini adalah minyak kelapa sawit. Biasanya elastomer bersumber dari minyak bumi yang tidak dapat diperbaharui sehingga menghasilkan karet sintetis, tetapi bioelastomer yang akan disintesis pada penelitian ini bersumber dari sumber daya alam yang dapat diperbaharui yaitu minyak kelapa sawit.

Sintesis bioelastomer yang bersumber dari minyak nabati telah diteliti oleh Cordier et al. (2008) dan Montarnal et al. (2008) yang dalam percobaannya tidak menggunakan minyak nabati secara langsung, namun menggunakan turunan asam lemak (fatty acid derivatives). Fatty dimer acid disintesis menjadi karet yang dapat memperbaiki diri sendiri (self-healing ability). Karet ini memiliki sifat elastis dan dapat disatukan kembali setelah diputuskan atau dirobek. Purbaya (2013) telah melakukan sintesis supramolekular polimer yang bersumber dari minyak bunga matahari, tetapi supramolekular polimer yang diperoleh hanya memiliki sifat healing ability yang rendah.

Pada penelitian ini akan dilakukan sintesis bioelastomer bersumber dari minyak kelapa sawit. Bioelastomer berbasis kelapa sawit yang diperoleh kemudian dicampur dengan karet alam dalam pembuatan kompon karet alam, dan selanjutnya dianalisis sifat mekanik komposit karet alamnya. Tujuan dari penelitian ini difokuskan untuk menghasilkan barang jadi karet yang tahan terhadap minyak yang baik.

\section{BAHAN DAN METODE}

Bahan yang digunakan dalam penelitian ini adalah minyak kelapa sawit. Dalam penelitian ini, sintesis bioelastomer akan dilakukan dalam tiga tahap (Gambar 1). Tahap pertama yaitu pembuatan asam dimer dari minyak kelapa sawit. Asam dimer adalah asam yang memiliki dua gugus fungsional asam karboksilat $(-\mathrm{COOH})$. Asam dimer dapat diperoleh dari reaksi Diels-Alder asam oleat atau asam linoleat. Gambar 2 adalah perkiraan mekanisme reaksi DielsAlder antara asam linoleat (memiliki dua ikatan rangkap) dengan asam akrilat (satu ikatan rangkap) dalam menghasilkan asam dimer (Kadesch, 1979).

Tahap kedua sintesis bioelastomer adalah pembuatan oligoamida dari asam dimer dengan mereaksikan asam dimer dan diethylenetriamine. Tahap ketiga adalah sintesis bioelastomer dengan mereaksikan oligoamida dengan urea. Perkiraan reaksinya dapat dilihat pada Tabel 1 . 


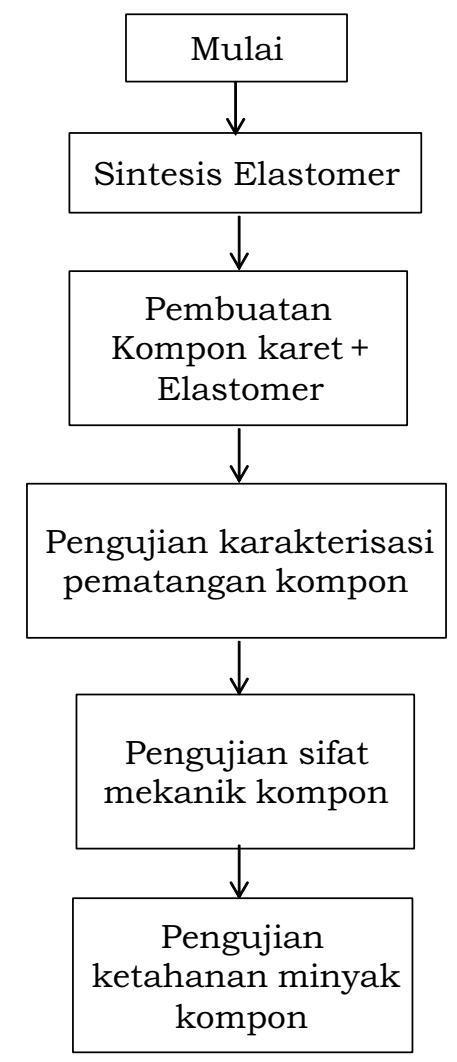

Gambar 1. Alur kerja penelitian

Figure 1. Stages of research activities

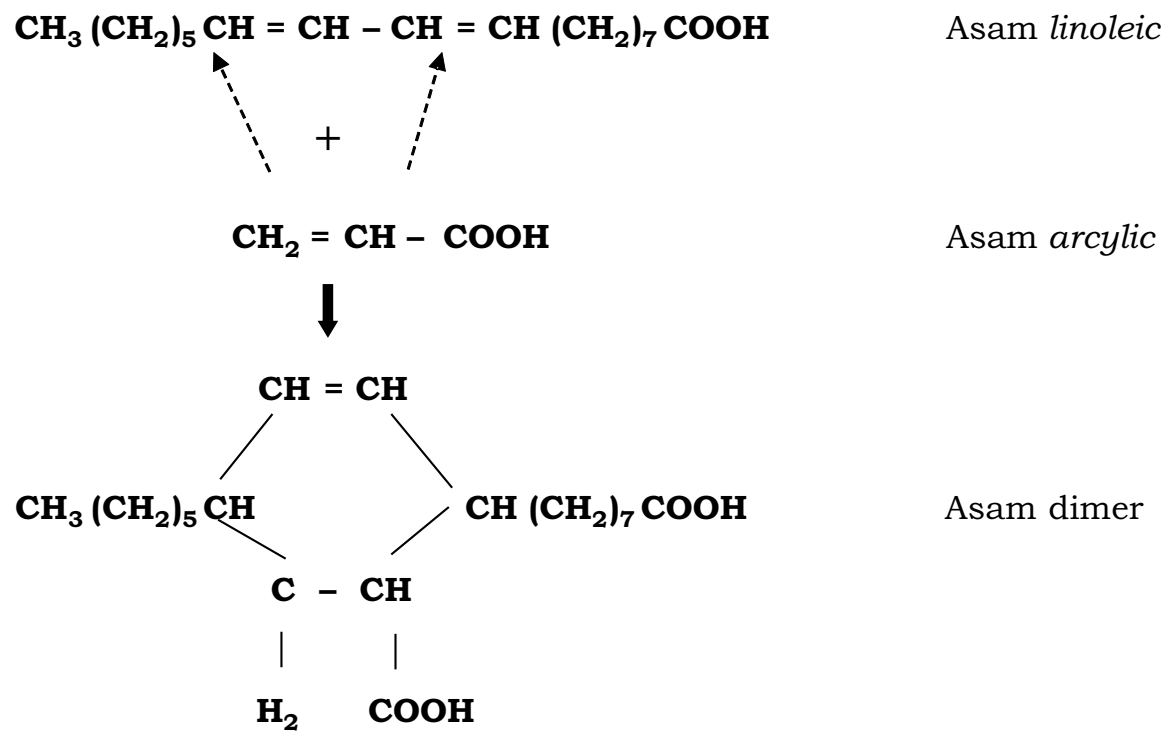

Gambar 2. Pembuatan asam dimer melalui reaksi Diels-Alder (Kadesch, 1979) Figure 2. Synthesize of dimer acid by using Diels-Alder reaction (Kadesch, 1979) 
Tabel 1. Pembuatan oligoamida dan sintesis bioelastomer Table 1. Synthesize of oligoamide and bioelastomer

Reactants $\begin{gathered}\text { Produk } \\ \text { Products }\end{gathered}$

Peralatan sintesis terdiri dari reaktor yang memiliki penutup berleher lima (Gambar 3), pengaduk mekanik, heating mantle, dan kondensor. Bahan yang akan digunakan terdiri dari minyak kelapa sawit, asam akrilat, iodine, diethylenetriamine, urea, kloroform, dan metanol. Penelitian ini dilakukan dari bulan Januari hingga Desember 2018. Pembuatan kompon karet alam dengan penambahan bioelastomer berbasis minyak kelapa sawit sebagai aditif dilakukan di Laboratorium Teknologi Balai Penelitian Sembawa. Sedangkan pengujian karakteristik pematangan dan sifat mekanik sampel komposit karet dilakukan di Laboratorium Penguji, Balai Penelitian Teknologi Karet, Bogor.

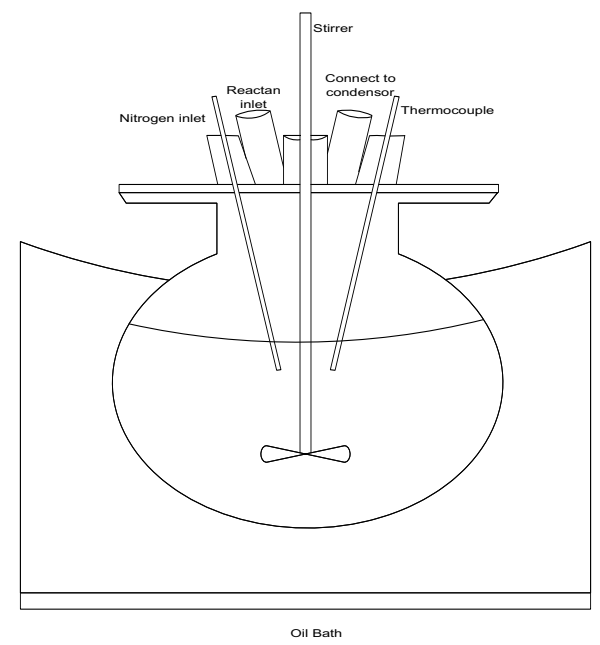

Gambar 3. Peralatan sintesis bioelastomer Figure 3. Bioelastomer synthesis equipment 


\section{Tahapan Sintesis Bioelastomer Berbasis Minyak Kelapa Sawit}

\section{Pembuatan Asam Dimer}

Minyak kelapa sawit terlebih dahulu dicampur dengan iodine kemudian diaduk dengan pengaduk mekanis pada suhu kamar. Banyaknya iodine yang ditambahkan adalah $0,1 \%$ dari berat minyak. Kemudian campuran dimasukkan ke dalam reaktor yang dilengkapi dengan kondensor, thermocouple, dan dropping funnel untuk menambahkan asam akrilat. Dosis penambahan asam akrilat dibuat bervariasi yaitu $12 \%$ dan $24 \%$ dari berat minyak nabati. Campuran dipanaskan pada suhu 230 $250^{\circ} \mathrm{C}$. Pada suhu $230^{\circ} \mathrm{C}$, asam akrilat ditambahkan setetes demi setetes. Reaksi dilakukan selama 1- 2 jam. Setelah reaksi selesai, campuran didinginkan pada suhu kamar.

\section{Pembuatan Oligoamida}

Oligoamida diperoleh dengan mereaksikan asam dimer dengan diethylenetriamine (DETA) di dalam reaktor yang dilengkapi dengan kondensor, thermocouple, pengaduk mekanis dan nitrogen inlet. Dosis DETA yang digunakan adalah $50 \%$ dari berat asam dimer. Campuran oligoamida dan DETA dipanaskan sampai suhu $120^{\circ} \mathrm{C}$ dengan dialirkan gas nitrogen sampai campuran menjadi transparan. Suhu campuran kemudian dinaikkan sampai suhu $160^{\circ} \mathrm{C}$ selama 6- 7 jam sambil dialiri gas nitrogen. Campuran yang diperoleh didinginkan pada suhu kamar. Campuran yang telah dingin kemudian dilarutkan dalam 250 g kloroform dan kemudian dicuci sebanyak lima kali dengan larutan metanol (campuran $120 \mathrm{~g}$ metanol dan $300 \mathrm{~g}$ air). Oligoamida yang diperoleh tersimpan sebagai larutan dalam kloroform.

\section{Sintesis Bioelastomer}

Sintesis bioelastomer dilakukan dengan mereaksikan oligoamida dengan urea. Sebelum sintesis dilakukan, kloroform sebagai pelarut oligoamida dikurangi volumenya menjadi satu per tiga bagian dari volume awal kloroform yang dilakukan dengan destilasi. Oligoamida yang telah berkurang kandungan kloroformnya kemudian dimasukkan ke dalam reaktor yang dilengkapi dengan pengaduk mekanik, thermocouple, dan inlet untuk menambahkan urea. Oligoamida dipanaskan pada suhu $80^{\circ} \mathrm{C}$ dengan aliran nitrogen selama 30 menit. Kemudian, urea ditambahkan ke dalam reaktor dengan dosis $25 \%$ dari berat oligoamida. Campuran kemudian dipanaskan pada suhu $160^{\circ} \mathrm{C}$. Temperatur dipertahankan konstan sampai campuran menjadi kental dan naik ke pengaduk mekanik sebagai tanda bahwa reaksi telah sempurna.

\section{Pencampuran Bioelastomer dan Karet Alam}

Proses pencampuran dilakukan pada mesin giling terbuka dengan berbagai variasi perbandingan bioelastomer berbasis minyak kelapa sawit dan karet alam. Pembuatan kompon dari campuran bioelastomer berbasis minyak kelapa sawit dan karet alam menggunakan formulasi kompon karet seperti diuraikan pada Tabel 2. Kompon karet kemudian diuji karakterisasi vulkanisasi, sementara vulkanisat karet diuji sifat mekaniknya untuk mengetahui pengaruh penambahan bioelastomer berbasis minyak kelapa sawit pada kompon karet padat.

\section{Pengujian Karakteristik Pematangan Kompon}

Pengujian karakteristik pematangan (Curing characteristic) kompon dilakukan dengan alat Rheometer Alpha 2000R pada suhu $150^{\circ} \mathrm{C}$ sesuai dengan ASTM 5289 (Standard Test Method for Rubber PropertyVulcanization Using Rotorless Cure Meters).

\section{Pengujian Sifat Mekanik Vulkanisat}

Pengujian sifat mekanik vulkanisat terdiri dari parameter kekerasan (ASTM D.2240-15), tegangan putus (ASTM D.41216), perpanjangan putus (ASTM D.412-16), kekuatan sobek (ASTM D.624-00(ra2012)), ketahanan retak lentur (ASTM D.62400(ra2012)), kepegasan pantul (Lupke) (ISO 4662:2017) dan pampatan tetap (ASTM D.395-16e1). 
Tabel 2. Formulasi kompon karet Table 2. Rubber compound formulation

\begin{tabular}{ccccccc}
\hline & \multicolumn{5}{c}{$\begin{array}{c}\text { Komposisi (bsk) } \\
\text { Compotition (phr) }\end{array}$} \\
\cline { 2 - 7 } Kode & $\begin{array}{c}\text { Karet alam } \\
\text { Natural } \\
\text { Rubber }\end{array}$ & $\begin{array}{c}\text { Elastomer } \\
\text { Elastomer }\end{array}$ & $\begin{array}{c}\text { Seng oksida } \\
\text { Zinc } \\
\text { Oxide }\end{array}$ & $\begin{array}{c}\text { Asam stearate } \\
\text { Stearic Acid }\end{array}$ & $\begin{array}{c}\text { MBT } \\
\text { MBT }\end{array}$ & $\begin{array}{c}\text { Belerang } \\
\text { Sulfur }\end{array}$ \\
\hline Kontrol B & 100 & 0 & 6 & 0,5 & 0,5 & 3,5 \\
B1 & 100 & 2,5 & 6 & 0,5 & 0,5 & 3,5 \\
B2 & 100 & 5 & 6 & 0,5 & 0,5 & 3,5 \\
B3 & 100 & 7,5 & 6 & 0,5 & 0,5 & 3,5 \\
B4 & 100 & 10 & 6 & 0,5 & 0,5 & 3,5 \\
B5 & 100 & 12,5 & 6 & 0,5 & 0,5 & 3,5 \\
B6 & 100 & 15 & 6 & 0,5 & 0,5 & 3,5 \\
\hline
\end{tabular}

\section{Pengujian Ketahanan Terhadap Minyak}

Pengujian terhadap minyak dilakukan dengan cara melakukan perendaman komposit hasil pencampuran karet alam dan bioelastomer di dalam minyak selama beberapa hari. Minyak yang akan digunakan adalah oli mesin. Pengujian ketahanan terhadap minyak dilakukan sesuai dengan metode ISO 1817:2005.

\section{HASIL DAN PEMBAHASAN}

Bioelastomer yang dihasilkan pada percobaan ini memiliki warna pucat dengan tekstur yang sangat keras sebagaimana diperlihatkan pada Gambar 4 sebagai berikut.

\section{Hasil Analisa Karakteristik Pematangan Kompon}

Karakteristik pematangan kompon terdiri dari parameter torsi maksimum $\left(\mathrm{S}_{\max }\right)$, torsi minimum $\left(\mathrm{S}_{\min }\right)$, delta torsi $\left(\mathrm{S}_{\max }-\mathrm{S}_{\min }\right)$, waktu pematangan optimum $\left(\mathrm{t}_{90}\right)$ dan waktu pra vulkanisasi $\left(\mathrm{ts}_{2}\right)$. Hasil pengujian karakteristik pematangan kompon karet dengan formula yang telah ditentukan dapat dilihat pada Tabel 3 .

Perlakuan penambahan bioelastomer ternyata dapat meningkatkan nilai torsi maksimum dan delta torsi, jika dibandingkan dengan kontrol. Hal ini menunjukkan bahwa bioelastomer yang ditambahkan pada kompon dapat meningkatkan derajat ikatan silang kompon. Delta torsi memberikan gambaran

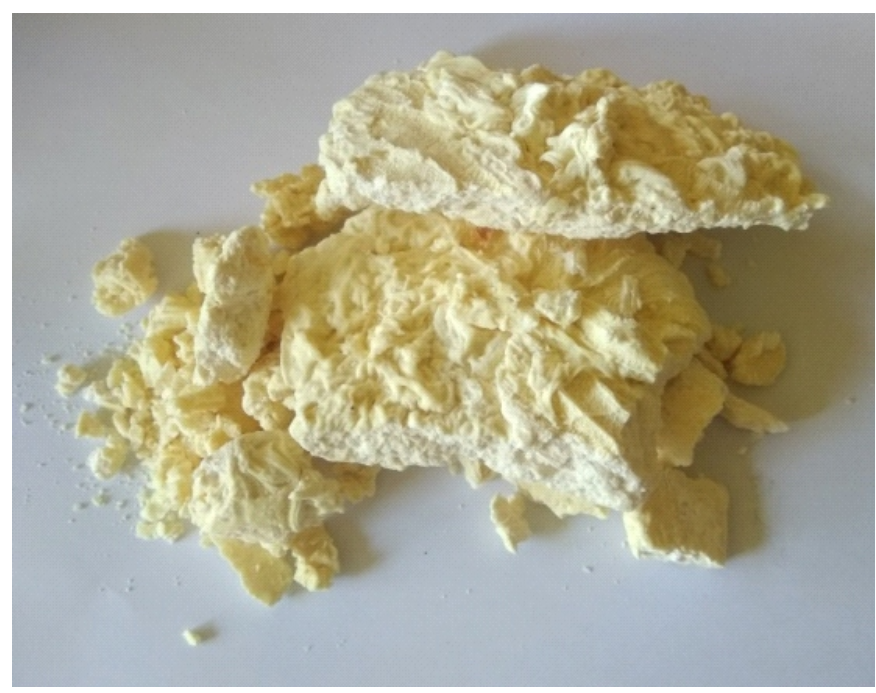

Gambar 4. Biolastomer dari minyak kelapa sawit Figure 4. Bioelastomeric based on palm oil 
Tabel 3. Karakteristik pematangan kompon

Table 3. Curing characteristics of compound maturation

\begin{tabular}{cccccc}
\hline $\begin{array}{c}\text { Kode } \\
\text { Code }\end{array}$ & $\begin{array}{c}\mathrm{S}_{\max } \\
(\mathrm{Kg} / \mathrm{cm})\end{array}$ & $\begin{array}{c}\mathrm{S}_{\min } \\
(\mathrm{Kg} / \mathrm{cm})\end{array}$ & $\begin{array}{c}\Delta \mathrm{S} \\
(\mathrm{Kg} / \mathrm{cm})\end{array}$ & $\begin{array}{c}\text { t90 } \\
(\mathrm{min}, \mathrm{sec})\end{array}$ & $\begin{array}{c}\mathrm{ts}_{2} \\
(\mathrm{~min}, \mathrm{sec})\end{array}$ \\
\hline Kontrol B & 5,28 & 0,68 & 4,60 & 20,58 & 7,42 \\
B1 & 8,13 & 0,80 & 7,33 & 20,46 & 4,05 \\
B2 & 8,02 & 0,38 & 7,64 & 19,08 & 2,40 \\
B3 & 7,64 & 0,90 & 6,74 & 19,04 & 3,03 \\
B4 & 7,69 & 0,42 & 7,27 & 18,54 & 3,23 \\
B5 & 6,02 & 0,45 & 5,57 & 18,16 & 3,19 \\
B6 & 7,18 & 0,73 & 6,45 & 17,54 & 3,00 \\
\hline
\end{tabular}

pembentukan jaringan dalam ikatan silang atau derajat ikatan silang (Javanovic et al., 2009). Derajat ikatan silang yang lebih besar dapat meningkatkan modulus, kekerasan dan menurunkan perpanjangan putus (Fathurrohman \& Ramadhan, 2015).

Berdasarkan Tabel 3, kompon dengan penambahan bioelastomer mempunyai waktu yang lebih singkat jika dibandingkan dengan kontrol. Menurut Yuniari et al. (2013), peningkatan suhu vulkanisat berpengaruh terhadap kecepatan waktu scorch, dikarenakan panas tersebut dapat juga meningkatkan reaksi antar molekul karet dan bahan lainnya. Sedangkan, optimum cure time merupakan waktu yang menunjukkan 90\% tingkat kematangan kompon (Alfa, 2005). Berdasarkan Tabel 3, penambahan bioelastomer dapat menurunkan waktu optimum pematangan kompon karet. Ibrahim et al. (2018) melaporkan bahwa ketebalan karet juga dapat mempengaruhi waktu pematangan kompon.

\section{Hasil Analisa Sifat Mekanik Kompon}

Hasil pengujian sifat mekanik vulkanisat komposit karet dengan penambahan bioelastomer berbasis minyak kelapa sawit sebagai bahan aditif kompon karet disajikan pada Gambar 5 hingga Gambar 12 sebagai berikut. Pengujian kekerasan dilakukan untuk mengetahui besarnya kekerasan vulkanisat karet dengan kekuatan penekanan tertentu. Nilai kekerasan dipengaruhi oleh jenis bahan pengisi dan bahan pelunak. Berdasarkan Gambar 5, penambahan bioelastomer dapat meningkatkan nilai kekerasan kompon jika dibandingkan perlakuan kontrol, kecuali untuk dosis bioelastomer sebesar 12,5 phr. Boonstra, (2005) menyatakan bahwa derajat ikatan silang yang berjumlah banyak dapat menyebabkan meningkatnya kekerasan pada kompon karet. Sedangkan Carli et al. (2011) menjelaskan bahwa peningkatan nilai kekerasan dimungkinkan terjadi karena adanya pemisahan bahan pengisi ke dalam matrik karet.

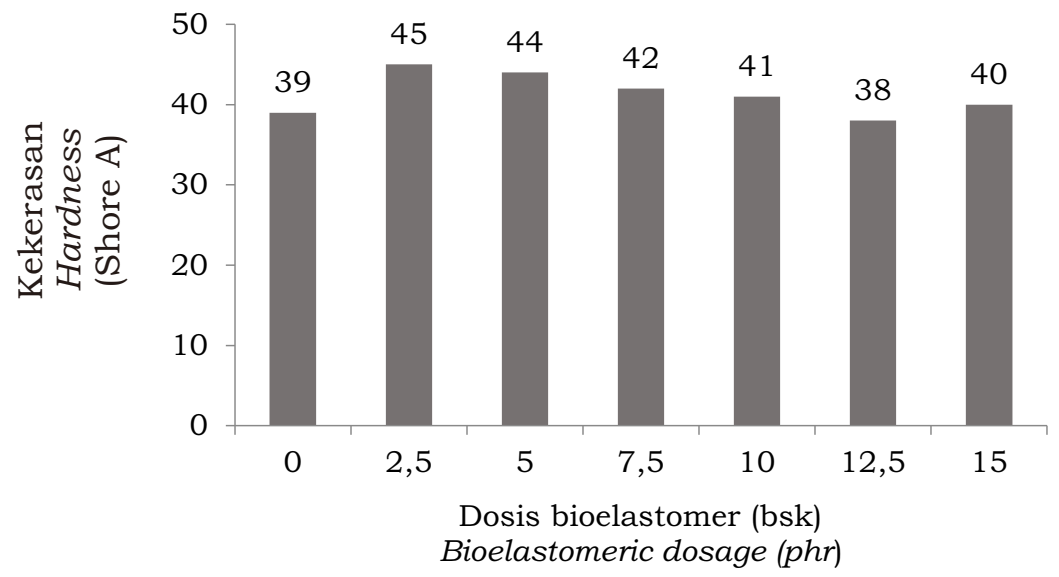

Gambar 5. Pengaruh dosis bioelastomer terhadap kekerasan vulkanisat.

Figure 5. Effect of bioelastomeric dosage on hardness of vulcanized 


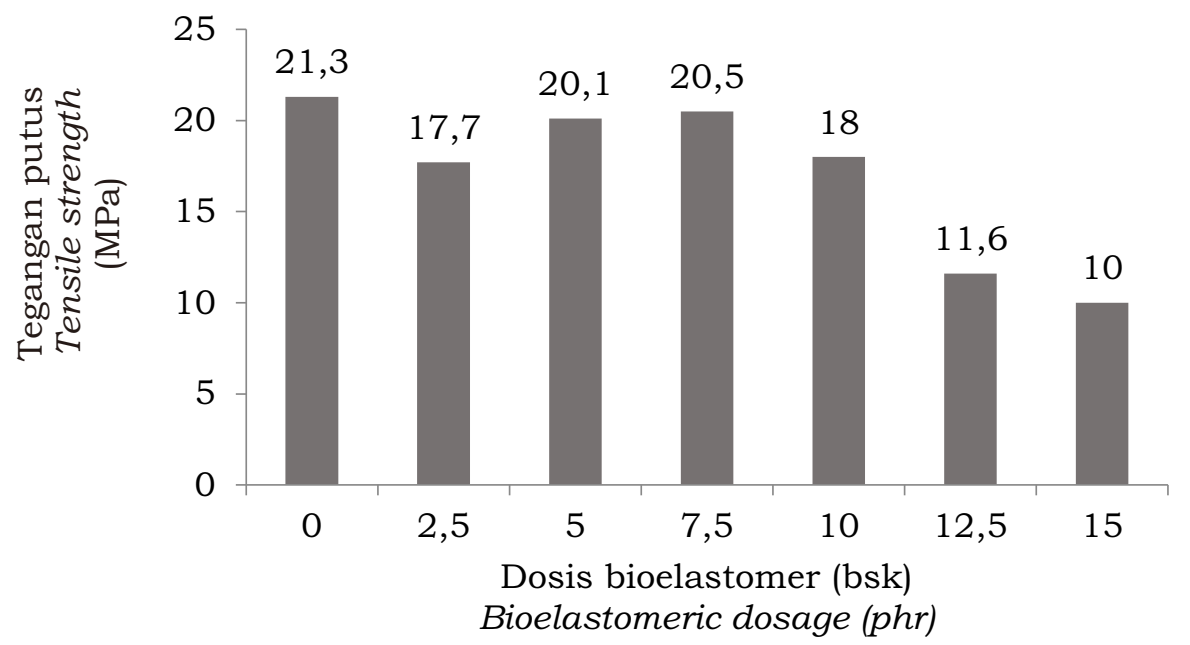

Gambar 6. Pengaruh dosis bioelastomer terhadap nilai tegangan putus vulkanisat Figure 6. Effect of bioelastomeric dosage on tensile strength of vulcanized

Tegangan putus menunjukkan besarnya beban yang diperlukan untuk merengangkan potongan uji sampai putus. Berdasarkan Gambar 6, penambahan bioelastomer dapat menurunkan nilai tegangan putus. Menurut Li et al. (2008) hal ini kemungkinan disebabkan oleh segmental mobilitas rantai polimer yang hilang. Untuk SNI tegangan putus, yaitu SNI 06-49661999, mengenai penentuan sifat - sifat tegangan dan regangan dari karet vulkanisat dan karet termoplastik, nilai yang dihasilkan minimal 45, sehingga memenuhi SNI tersebut. Perpanjangan putus adalah penambahan panjang suatu potongan uji bila direngangkan sampai putus. Berdasarkan Gambar 7, penambahan bioelastomer menurunkan perpanjangan putus vulkanisat. Hal yang sama dilaporkan oleh Ashri et al. (2014) bahwa penambahan dosis elastomer 25 phr dapat menghasilkan kompon karet yang rendah sifat kekerasan dan kekenyalannya. Sedangkan berdasarkan SNI perpanjangan putus memenuhi kriteria, yaitu SNI 06-4966-1999, mengenai penentuan sifat - sifat tegangan dan regangan dari karet vulkanisat dan karet termoplastik dengan nilai yang dihasilkan minimal 250\%.

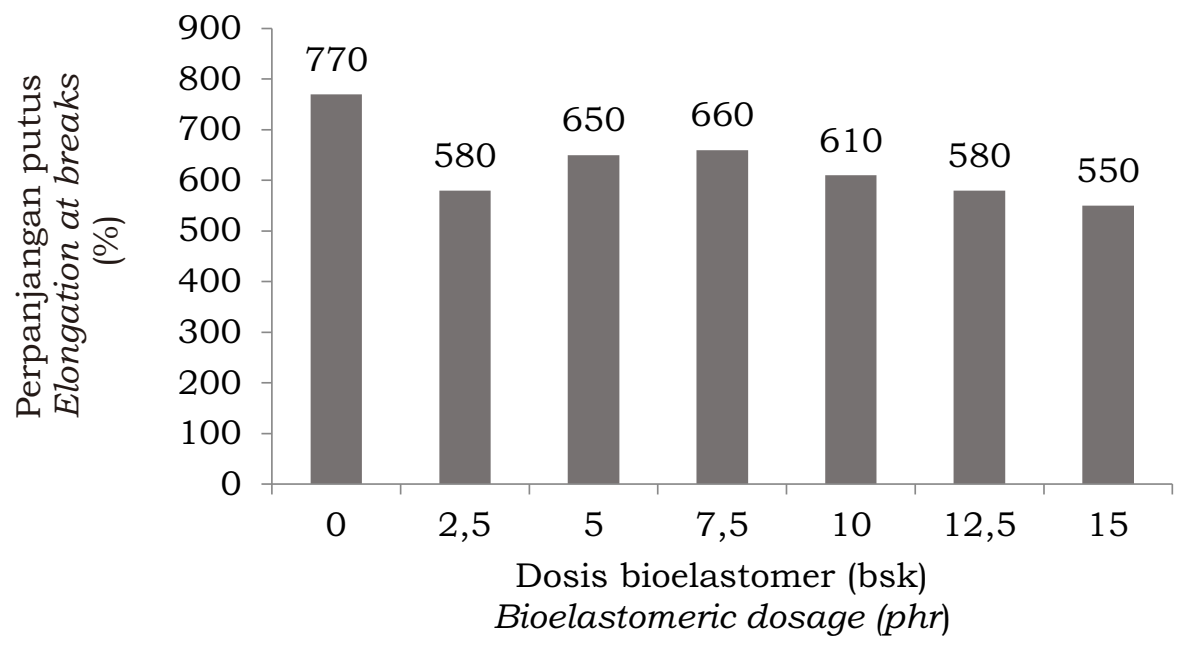

Gambar 7. Pengaruh dosis bioelastomer terhadap nilai perpanjangan putus vulkanisat Figure 7. Effect of bioelastomeric dosage on elongation at breaks of vulcanized 


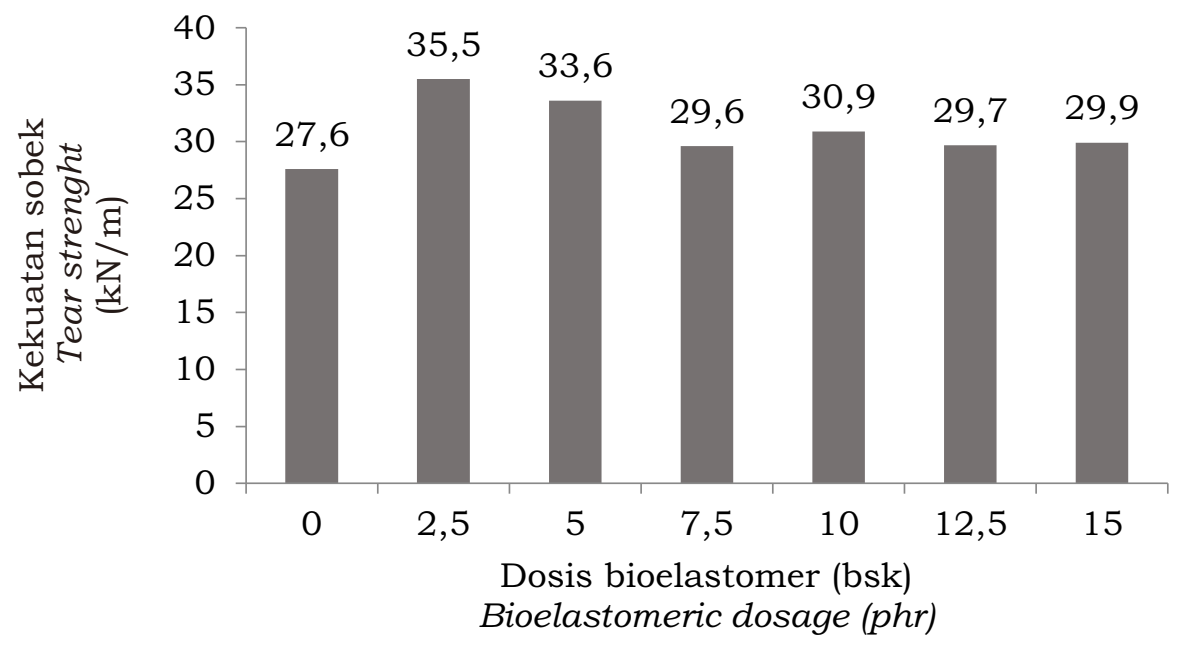

Gambar 8. Pengaruh dosis bioelastomer terhadap nilai kekuatan sobek vulkanisat Figure 8. Effect of bioelastomer dosage on tear strength of vulcanized

Kekuatan sobek adalah besarnya tenaga yang dibutuhkan untuk menarik vulkanisat karet alam sampai putus. Dengan demikian berarti semakin besar nilai kekuatan sobek maka semakin besar tenaga yang dibutuhkan untuk menarik karet alam hingga putus (Vachlepi \& Suwardin, 2015). Berdasarkan Gambar 8, dapat diketahui bahwa penambahan bioelastomer dapat meningkatkan kekuatan sobek vulkanisat karet jika dibandingkan dengan kontrol. Untuk kekuatan sobek, SNI nya adalah SNI 06-0899-1989 mengenai lembaran karet cetak sol, yaitu memiliki nilai $50 \mathrm{~kg} / \mathrm{cm}^{2}$.

Ketahanan retak lentur dilakukan untuk mengetahui besarnya kerusakan karet jika dilenturkan atau dilekukkan berulang kali secara terus menerus melalui pengujian ketahanan letih dinamik. Berdasarkan Gambar 9, penambahan bioelastomer dapat menurunkan nilai ketahanan retak lentur karet. Untuk percobaan ini, semua perlakuan mempunyai nilai ketahanan retak lentur di bawah kontrol, kecuali untuk formulasi B6. Alahkawi et al. (2013) melaporkan bahwa karet sintetis Polybutadiene berpotensi memiliki nilai retak lentur yang tinggi pada produksi ban kendaraan.

Uji kepegasan pantul dilakukan untuk mengetahui persentase daya pantul dari vulkanisat karet sebagai gambaran dari hilangnya energi histeresis. Dari Gambar 10, penambahan bioelastomer hanya sedikit

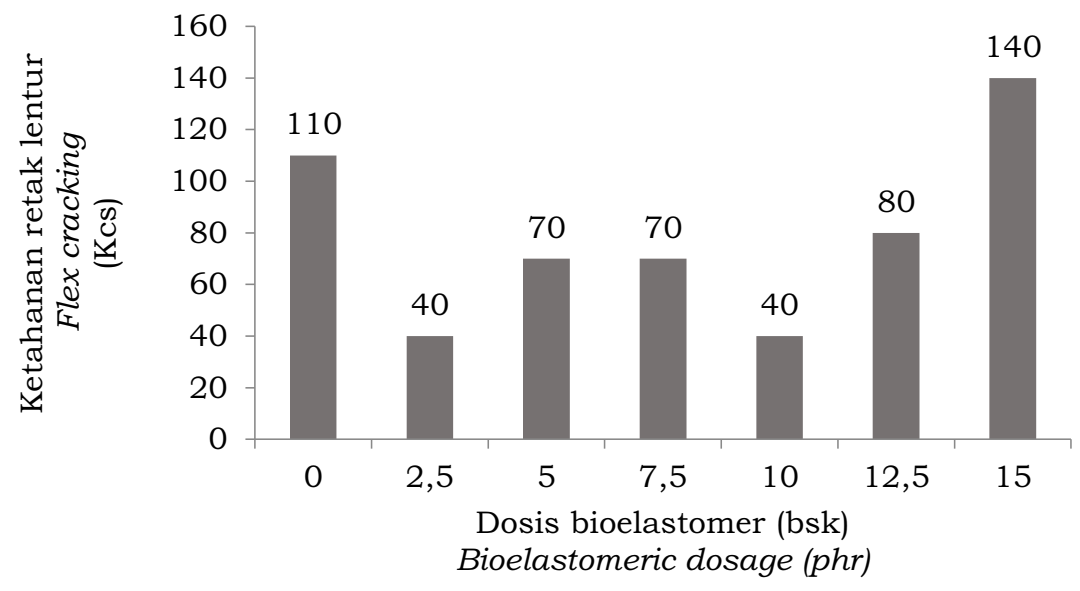

Gambar 9. Pengaruh dosis bioelastomer terhadap nilai ketahanan retak lentur vulkanisat Figure 9. Effect of elastomeric dosage on flex crack resistance of vulcanized 
meningkatkan nilai kepegasan pantul karet, bahkan penambahan dosis bioelastomer lebih lanjut akan menurunkan nilai kepegasan pantul. Untuk uji kepegasan pantul, SNI nya memenuhi standar, yaitu SNI 12-01721987, mengenai sol sepatu sebesar minimal 30\%.

Uji pampatan tetap dilakukan untuk mengetahui sifat elastik vulkanisat karet setelah ditekan pada waktu tertentu dan kondisi tertentu, terutama untuk vulkanisat yang dalam pemakaiannya mengalami penekanan. Berdasarkan Gambar 11, penambahan bioelastomer pada karet dapat menurunkan sifat pampatan tetap karet, karena semakin tinggi dosis bioelastomer maka semakin tinggi nilai pampatan tetap karet yang dihasilkan. Ali et al. (2017) melaporkan bahwa mendapatkan nilai sebesar 8,3\%, sedangkan Egwaikhide menghasilkan penurunan nilai untuk uji pampatan sebesar 39 menjadi $5 \%$.

\section{Hasil Pengujian Ketahanan Minyak}

Vulkanisat karet pada percobaan ini juga diuji ketahanannya terhadap minyak dengan menggunakan oli mesin komersial. Hasil pengujian dapat dilihat pada Gambar 12. Dari hasil pengujian, diketahui bahwa perlakuan B3 memiliki nilai perubahan massa yang paling rendah dibandingkan dengan perlakuan lainnya, bahkan terhadap perlakuan kontrol. Ini menunjukkan bahwa formulasi kompon B3 berpotensi dikembangkan menjadi produk barang jadi karet yang memiliki sifat ketahanan terhadap minyak yang unggul.

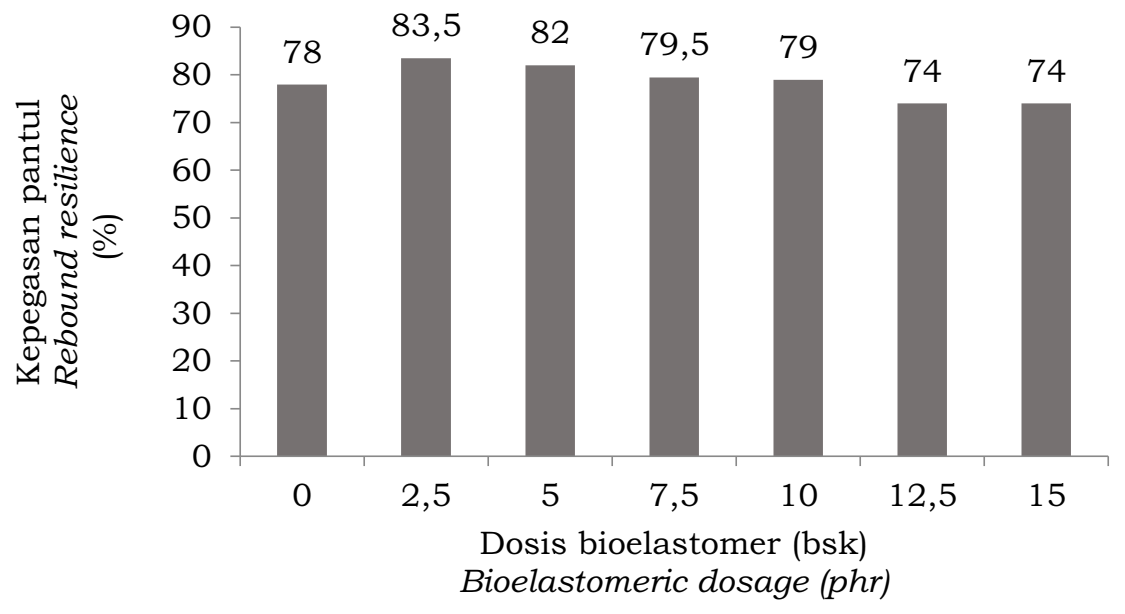

Gambar 10. Pengaruh dosis bioelastomer terhadap nilai kepegasan pantul vulkanisat Figure 10. Effect of bioelastomeric dosage on rebound resilience of vulcanized

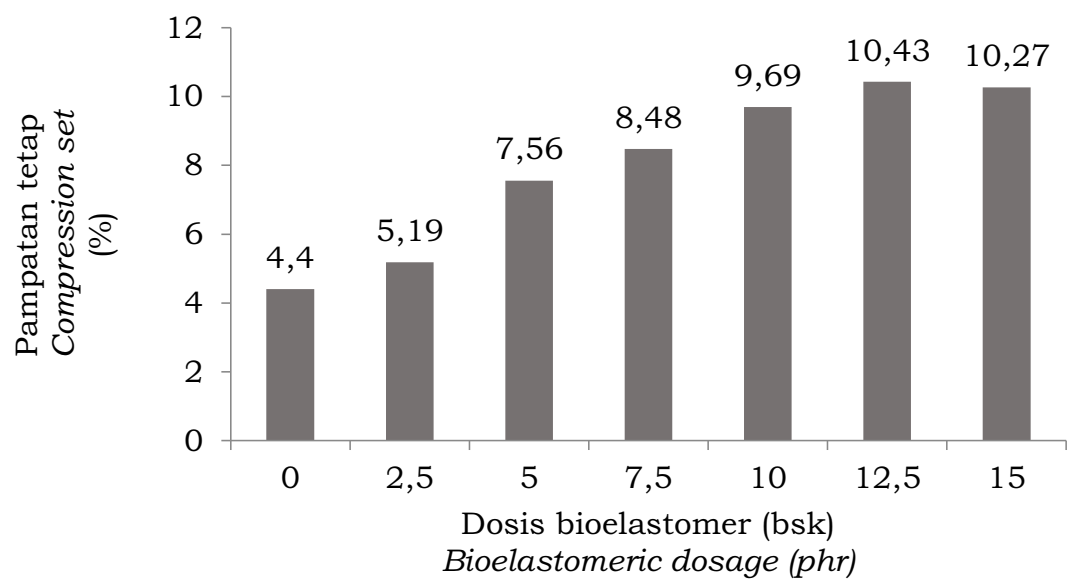

Gambar 11. Pengaruh dosis bioelastomer terhadap nilai pampatan tetap vulkanisat

Figure 11. Effect of elastomeric dosage on compression set of vulcanized 


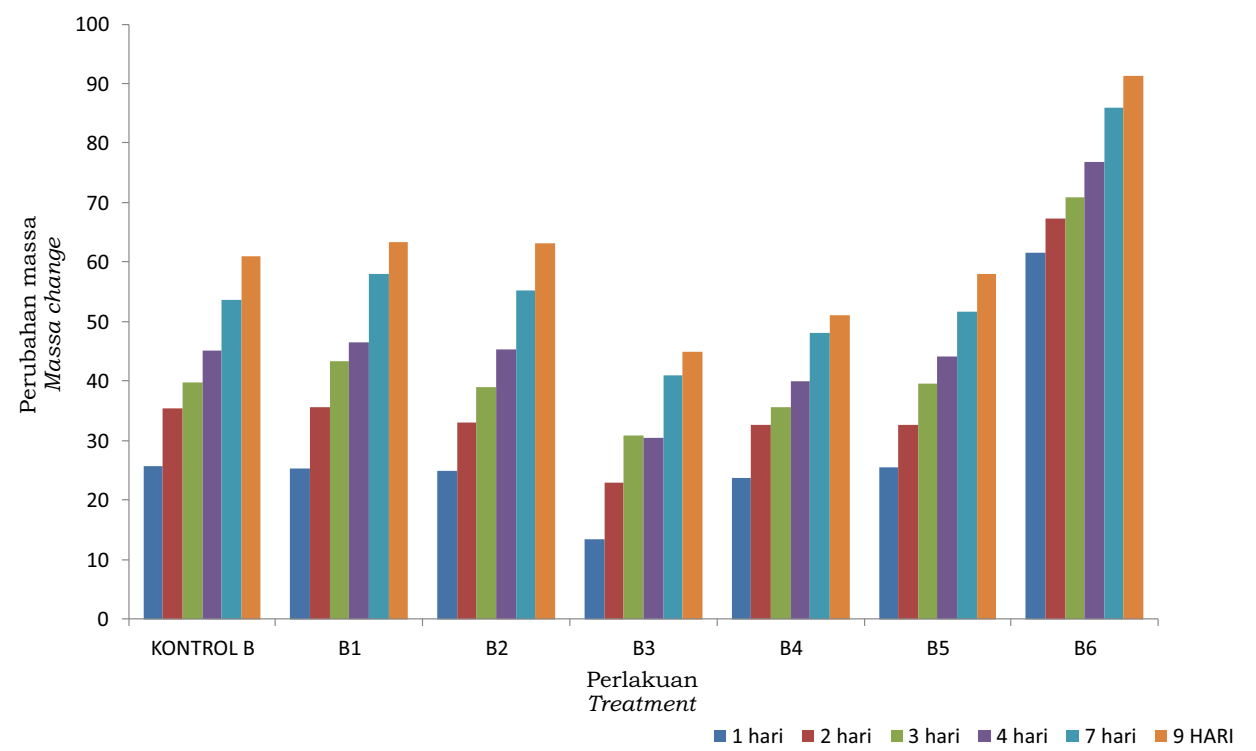

Gambar 12. Uji ketahanan minyak vulkanisat

Figure 12. Oil resistance test of vulcanized

\section{KESIMPULAN}

Pembuatan bioelastomer dari minyak kelapa sawit pada percobaan ini dilakukan dengan penambahan asam akrilat dan urea pada komposisi tertentu. Bioelastomer yang dihasilkan dari percobaan ini memiliki tekstur yang keras. Pengaruh bioelastomer pada karakterisasi pematangan kompon karet menunjukkan bahwa penambahan bioelastomer dapat meningkatkan nilai torsi maksimum, delta torsi dan menurunkan waktu pra vulkanisasi serta waktu pemasakan optimum. Sementara pengaruh bioelastomer pada sifat mekanik vulkanisat menunjukkan bahwa penambahan bioelastomer dapat meningkatkan nilai kekerasan, kekuatan sobek, dan pampatan tetap karet, tetapi menurunkan nilai tegangan putus, perpanjangan putus, ketahanan retak lentur, dan nilai kepegasan pantul vulkanisat. Hasil pengujian ketahanan minyak vulkanisat menunjukkan bahwa formula karet B3 (dosis penambahan bioelastomer sebesar 7,5 phr) memiliki nilai perubahan massa yang paling kecil sehingga formula kompon B3 dapat dikembangkan menjadi formula untuk produk barang jadi karet yang tahan terhadap minyak.

\section{DAFTAR PUSTAKA}

Al-Alkawi, H.J., Al-Fattal, D.S., \& Abd-Ali, N.K. (2013). The flexing fatigue properties of filled rubbery compounds under constant and variable amplitude. JKAU: Engineering Science, 24(2), 57-79. https://doi.org/ 10.4197/Eng.24-2.3

Alfa, A.A. (2005). Bahan Kimia untuk Kompon Karet. Bogor, Indonesia: Balai Penelitian Teknologi Karet Bogor.

Ashri, A., Yusof, M.S.M., Jamil, M.S., Abdullah, A., Yusoff, S.F.M., Arip, M.N.M., \& Lazim, A.M. (2014). Physicochemical characterization of starch extracted from Malaysian wild yam (Dioscorea hispida Dennst.). Emirates Journal of Food and Agriculture, 26(8), 652. https:// doi.org/10.9755/ejfa.v26i8.17098

Boonstra, B.B. (2005) Reinforcement by filler. J. Rubber Age 92 (6) : 227 \pm 235. Dalam: Marlina, P., F. Pratama, B. Hamzah \& R. Pambayun (2014). Pengaruh Suhu dan lama penyimpanan terhadap karakteristik kompon karet dengan bahan pengisi arang tempurung kelapa dan nano silica sekam padi. Jurnal Dinamika Penelitian Industri, 25(1), 43-51. http://dx.doi.org/10.28959/jdpi.v25i 1.677 
Carli, L.N., Roncato, C.R., Zanchet, A., Mauler, R.S., Giovanela, M., Brandalise, R.N., \& Crespo, J.S. (2011). Characterization of natural rubber nanocomposites filled with organoclay as a substitute for silica obtained by the conventional two-roll mill method. Applied Clay Science, 52, 56-61. https://doi.org/10.1016 /j.clay.2011.01.029

Cordier, P., Tournilhac, F., Soulié-Ziakovic, C., \& Leibler, L. (2008). Self-healing and thermorversible rubber from supramolecular assembly. Nature, 451, 977-980. https://doi.org / 10.1038/nature06669

Fathurrohman, M.I., \& Ramadhan, A. (2015). Sifat mekanik vulkanisat campuran karet alam-karet polibutadien dengan bahan pengisi organobentonit terekspansi. Jurnal Penelitian Karet, 33(1), 65-74. https://doi.org/ 10.22302/ppk.jpk.v3 3i1.172

Harwood, H. J. (1962). Reactions of the hydrocarbon chain of fatty acids. Chemical Reviews, 62(2), 99-154. https:/ / doi.org/ 10.1021/cr60216a00 22

Ibrahim, S.Z., Engku, Z.E.Z., Ahmad, M.A., $\&$ Samsuri, A. (2018). Cure characteristics and mechanical properties of different accelerator systems for thick rubber article. National Symposium on Polymeric Materials 2017 (NSPM 2017) AIP Conf. Proc. 1985, 040012-1-040012-6. https: / / doi.org/ 10.1063/1.5047189

Jovanovic, V., Simendic, B.J., Jovanovic, S.S., Moarkovic, G., \& Concovic, M.M. (2009). The influence of carbon black on curing kinetics and thermal aging of acrilonitrile-butadiene rubber. Chemical Industry \& Chemical Engineering, 15(4), 283-289. http: / / dx.doi.org/ 10.2298/CICEQ09 04283J

Kadesch, R.G. (1979). Fat-based dibasic acid. Journal of the American Oil Chemists' Society, 56(11), 845A-849A. https://doi.org/10.1007/BF0266746 0
Ketaren, S. (1986). Pengantar Teknologi Minyak dan Lemak Pangan. Jakarta, Indonesia: Universitas Indonesia.

Li, Z.H., Zhang, J., \& Chen, S.J. (2008). Effects of carbon blacks with various structures on vulcanization and $\mathrm{reinforcement}$ of filled ethylenepropylene-diene rubber. eXPRESS Polymer Letters, 2(10), 695704. https://doi.org/10.3144 /expresspolymlett.2008.83

Montarnal, D., Cordier, P., Soulié-Ziakovic, C., Tournilhac, F., \& Leibler, L. (2008). Synthesis of self-healing supramolecular rubbers from fatty acid derivatives, diethylene triamine, and urea. Journal of Polymer Science. Part A : Polymer Chemistry, 46(24), $7925-7936$. https://doi.org / 10.1002/pola.23094

Purbaya, M. (2013). Synthesis and characterization of supramolecular polymer based on linoleic acid of sunflower oil. [Tesis]. Kuala Lumpur, Malaysia: Universiti Teknologi Malaysia.

Vachlepi, A., \& Suwardin, D. (2015). Kajian pembuatan kompon karet alam dari bahan pengisi abu briket batubara dan arang cangkang sawit. Jurnal Dinamika Penelitian Industri, 26(1), 119. http://dx.doi.org/10.28959/ jdpi.v26i1.696

Yuniari, A., Mayasari, H. E., \& Setyorini, I. (2017). Curing characteristics, swelling, and mechanical properties of natural rubber / nitrile butadiene rubber blends with and without compatibilizer, Majalah Kulit Karet Plastik, $33(2), 65-72$. http: / / dx.doi.org/10.20543/mkkp. v33i2.3265 